\title{
Analisis Risiko Kegemukan pada Remaja dan Dewasa Muda
}

\section{Risk Factors Analysis of Overweight on Adolescent and Youth Adults}

\author{
Purwo Setiyo Nugroho' ${ }^{*}$, Sudirman ${ }^{1}$ \\ ${ }^{1}$ Universitas Muhammadiyah, Kalimantan Timur, Indonesia \\ *Korespondensi penulis: purwo.skm@umkt.ac.id
}

Penyerahan: 15-09-2020, Perbaikan: 11-12-2020, Diterima: 13-12-2020

\begin{abstract}
Indonesia is experiencing problems with non-communicable diseases, one of which is adolescent obesity, which is recorded to have increased according to the 2010 and 2013 Basic Health Research. The results of a preliminary survey at a Puskesmas recorded that around 200 students were overweight. This study aims to analyze the risk of obesity in adolescents and young adults in Samarinda City. The research design of this study used a Cross Sectional with the help of Google Form in collecting research data in the COVID19 pandemic. The number of samples in this study were 416 respondents aged 13-24 years. Chi Square statistical analysis is used to answer the research objectives. The results showed that the variable status of the parents who have obesity at risk of obesity is adolescents and young adults ( $p$-value 0.034, OR 1.629, 95\% CI 1.058-2.506). Obesity in adolescents and young adults tends to be due to the behavior of parents who behave in a less healthy way, so there is a need for education to parents through affordable media so that they can live healthy behavior because it will affect the obesity status of children, in this case what is meant by adolescents and young adults.
\end{abstract}

Keywords: Overweight, Adolescents, Young Adults, Indonesia.

\begin{abstract}
ABSTRAK
Indonesia mengalami permasalahan penyakit tidak menular, salah satunya adalah kegemukan pada remaja yang tercatat mengalami peningkatan menurut Riset Kesehatan Dasar tahun 2010 dan 2013. Hasil survey pendahuluan di sebuah Puskesmas tercatat sekitar 200 siswa mengalami kegemukan. Penelitian ini bertujuan untuk menganalisis risiko kejadian kegemukan pada remaja dan dewasa muda di Kota Samarinda. Desain penelitian penelitian ini menggunakan Cross Sectional dengan bantuan Google Form dalam pengambilan data penelitian ditengan pandemic COVID-19. Jumlah sampel pada penelitian ini sejumlah 416 responden yang berumur 13-24 tahun. Analisis statistik Chi Square digunakan untuk menjawab tujuan peneitian. Hasil penelitian didapatkan bahwa variabel status orang tuan yang memilik kegemukan berisiko terjadinya kegemukan ada remaja dan dewasa muda ( $p$-value 0.034, OR 1.629, CI 95\% 1.058-2.506). Kegemukan pada remaja dan dewasa muda cenderung dikarenakan perilaku orang tua yang berperilaku hidup kurang sehat sehingga perlu adanya edukasi kepada orang tua melalui media yang terjangkau agar hidup berperilaku sehat karena akan mempengaruhi status kegemukan pada anak, dalam hal ini yang dimaksud adalah remaja dan dewasa muda.
\end{abstract}

Kata kunci: Kegemukan, Remaja, Dewasa Muda, Indonesia. 


\section{PENDAHULUAN}

Indonesia sedang mengalami permasalahan ganda kesehatan, selain permasalahan penyakit menular yang sedang merajalela saat ini, Indonesia juga memiliki permasalahan lain yakni penyakit tidak menular (Sidiartha \& Juliantini, 2015). Tidak dapat dipungkiti bahwa penyakit tidak menular ini lebih banyak dikarenakan perilaku orang secara pribadi yang terakumulasi dari waktu lampau (Caesarianna \& Indriawati, 2016). Kegemukan merupakan suatu permasalahan penyakit tidak menular yang akan menimbulkan dampak penyakit tidak menular lainnya seperti penyakit jantung coroner, diabetes mellitus dan lainnya. Permasalahan kegemukan tidak hanya terjadi pada usia dewasa saja, namun usia remaja dan dewasa muda mulai banyak yang menderita kegemukan. Kegemukan pada usia muda akan berisiko berlanjut hingga usia tua sehingga perlu adanya upaya intervensi yang tepat (Kurdanti et al., 2015).

$$
\text { Laporan World Health }
$$
Organization mengungkapkan bahwa 1 dari 3 remaja mengalami kegemukan di dunia. Kasus kegemukan di Amarika Serikat tercatat bahwa remaja umur 12-19 tahun menderita kegemukan sebesar $5 \%$ pada tahun 1980 dan terus meningkat hingga tahun 2012 sebesar 21\%. Riset Kesehatan Dasar tahun 2013 mengungkapkan bahwa kegemukan pada usia remaja berumur 16-18 tahun mengalami peningkatan dari tahun 2010 sebesar $1.4 \%$ menjadi $7.3 \%$ pada tahun 2013. Hal ini juga dikarenakan masa remaja merupakan masa tumbuh kembang yang sangat cepat untuk masuk dalam periode perkembangan selanjutnya. Selain itu masa remaja juga mengalami fase penyesuaian gaya hidup terutama dalam kebiasaan

makan

yang

menyesuaiakan dengan energy dan zat gizi yang diperlukan tubuh. Survei pendahuluan yang dilakukan disalah satu Puskesmas di Kota Samarinda mendapatkan bahwa sekitar 200 siswa menderita kegemukan di wilayah kerjanya yang didapatkan dari penjaringan kesehatan sekolah (Salam, 2010).

Beberapa peneliti menemukan beberapa faktor penyebab kegemukan pada remaja dan dewasa muda yakni genetik, kurangnya aktivitas fisik (Nugroho, Wijayanti, et al., 2020). Bahkan di negara barat dilaporkan bahwa kegemukan pada masa remaja dan dewasa muda dikarenakan status kegemukan pada orang tua mereka. Tak dapat dipungkiri bahwa faktor lain juga mempengaruhi kegemukan pada remaja dan dewasa muda. Penelitian di Arab Saudi menemukan bahwa kejadian kegemukan di negara tersebut disebabkan oleh kebiasaan makan makanan berlema, makanan cepat saji dan kurangnya konsumsi makanan berserat (Mahfouz et al., 2011). Banyaknya asusmsi mengenai penyebab kegemukan pada remaja maka penelitian ini bertujuan untuk mengetahui risiko penyebab kegemukan pada remaja di Kota Samarinda.

\section{METODE}

Penelitian ini menggunakan desain Crossectional dimana seluruh variabel penelitian (variabel bebas dan terikat) diambil informasinya dalam satu waktu secara bersamaan (Johnson et al., 2015). Jumlah responden pada penelitian ini sebesar 416 responden yang dihitung menggunakan rumus Lameshow pada dua proporsi populasi dengan bantuan aplikasi Sample Size. Desain sampling penelitian ini menggunakan desain Non-Random Sampling dengan 
teknik Convenience Sampling dengan menggunakan bantuan google form, hal ini dilakukan karena keterbatasan penelitian saat pandemic untuk meminimalisir kontak langung dengan responden. Kriteria inklusi pada penelitian ini adalah responden yang berusia 13 24 tahun, berdomisili di Kota Samarinda dan mengisi lengkap kuesioner peneltiian, sedangkan kriteria ekslusi adalah responden yang memiliki status gizi kurang tidak diikutkan dalam analisis data. Variabel penelitian dalam penelitian ini antara lain kebiasaan makan makanan cepat saji, kebiasaan minum minuman bersoda, orang tua yang berstatus gemuk, kebiasaan berolahraga, kebiasaan makan gorengan, pecandu game, status merokok dan kegemukan. Kuesioner penelitian telah dinyatakan valid dan HASIL reliable setelah sebelumnya diuji validitas dan reliabilitas kuesioner. Adapun isi dari kuesioner menanyakan variabel penelitian dan pertanyaan mengenai karakteristik responden. Variabel penelitian yang dimaksud antara lain hobi makan makanan cepat saji, hobi minum minuman bersoda, memiliki orang tua yang berstatus gemuk, berolahraga, suka makan gorengan, pecandu game, bukan perokok dan responden tidak gemuk. Variabel kegemukan diukur dengan menghitung Indeks Masa Tubuh responden. Analisis data dalam penelitian ini menggunakan Chi Square dengan bantuan aplikasi statistik komputer yang bertujuan untuk mengukur risiko variabel bebas terhadap variabel terikat.

\begin{tabular}{lcccc}
\multicolumn{6}{c}{ Tabel 1 Karakteristik Individu Responden Penelitian } \\
\hline \multicolumn{1}{c}{ Variabel } & Jumlah (Persentase) & Rerata & Min & Maks \\
\hline Jenis Kelamin & & & & \\
- Laki-laki & $85(20.4 \%)$ & - & - & - \\
- Perempuan & $331(79.6 \%)$ & - & - & - \\
Umur & - & 19.48 & 10 & 35 \\
Tinggi Badan & - & 155.40 & 140 & 170 \\
Berat Badan & - & 59.71 & 45 & 80 \\
\hline
\end{tabular}

Tabel 1 menjelaskan mengenai distribusi frekuensi variabel karakteristik responden, dari table tersebut dapat dijelaskan bahwa sebagian besar responden adalah perempuan, rata-rata umur responden 19.48 tahun, rata-rata tinggi badan $155.40 \mathrm{~cm}$ dan ratarata berat badan responden 59.71 $\mathrm{Kg}$.

Tabel 2 Distribusi Frekuensi Risiko Kegemukan Pada Remaja

\begin{tabular}{lcc}
\hline \multicolumn{1}{c}{ Variabel } & Jumlah & Persen (\%) \\
\hline Hobi Makan Makanan Cepat Saji & & \\
- Ya (> 7 kali/bulan) & 346 & 83.2 \\
- Tidak (tidak pernah/jarang) & 70 & 16.9 \\
\hline Hobi Minum Minuman Bersoda & & \\
- Ya (> 10 kali/bulan) & 133 & 32 \\
- Tidak (tidak pernah/jarang) & 283 & 68 \\
\hline Hobi Minum Minuman Manis & & \\
- Ya (> 7 kali/minggu) & 297 & 71.4 \\
- Tidak (tidak pernah/jarang) & 119 & 28.6 \\
\hline Orang Tua Gemuk & & \\
\hline
\end{tabular}




\begin{tabular}{lcc}
\hline \multicolumn{1}{c}{ Variabel } & Jumlah & Persen (\%) \\
\hline - Ya & 219 & 52.6 \\
- Tidak & 197 & 47.4 \\
\hline Olahraga & & \\
- Ya (lebih 30 menit/hari) & 83 & 20 \\
- Tidak (kurang 30 menit/hari) & 333 & 80 \\
\hline Makan Gorengan & & \\
- Ya & 298 & 71.6 \\
- Tidak & 118 & 28.4 \\
\hline Pecandu Game Online & & \\
- Ya & 67 & 16.1 \\
- Tidak & 349 & 83.9 \\
\hline Perokok & & \\
- Ya & 14 & 3.4 \\
- Tidak & 402 & 96.6 \\
\hline Status Kegemukan & & \\
- Gemuk & 121 & 29.1 \\
- Normal & 295 & 70.9 \\
\hline
\end{tabular}

Tabel 2 menjelaskan mengenai distribusi frekuensi variabel risiko dan variabel status kegemukan pada responden penelitian. Hasil analisis pada table 2 dapat disimpulkan bahwa sebagian besar responden hobi makan makanan cepat saji $(82.2 \%)$, tidak hobi minum minuman bersoda $(68 \%)$, memiliki orang tua yang berstatus gemuk (52.6\%), tidak berolahraga $(80 \%)$, suka makan gorengan (71.6\%), bukan pecandu game $(83.9 \%)$, bukan perokok (96.6\%) dan responden tidak gemuk (70.9\%).

\section{Tabel 3 Analisis Chi Square Faktor Risiko Kegemukan Pada Responden}

\begin{tabular}{lccc}
\hline \multicolumn{1}{c}{ Variabel } & p-value & OR & CI 95\% \\
\hline Hobi Makan Makanan Cepat Saji & 0.365 & 0.747 & $0.432-1.290$ \\
Hobi Minum Minuman Bersoda & 0.058 & 0.615 & $0.381-0.990$ \\
Hobi Minum Minuman Manis & 0.926 & 0.978 & $0.613-1.561$ \\
Orang Tua Gemuk & 0.034 & 1.629 & $1.058-2.506$ \\
Olahraga & 0.086 & 0.621 & $0.374-1.031$ \\
Makan Gorengan & 0.499 & 1.214 & $0.752-1.960$ \\
Pecandu Game Online & 0.141 & 1.569 & $0.907-1.933$ \\
Perokok & 0.146 & 2.526 & $0.867-7.364$ \\
\hline
\end{tabular}

Tabel 3 merupakan hasil analisis Chi Square yang menghubungkan seluruh variabel bebas (risiko) terhadap variabel terikat (kegemukan). Dari hasil analisis didapatkan bahwa hanya variabel status orang tua yang memiliki kegemukan berhubungan dengan status kegemukan pada responden penelitian ( $p$-value 0.034). Hasil analisis juga menjelaskan bahwa responden yang memiliki orang tua yang kegemukan berisiko 1.629 kali menderita kegemukan daripada respoden yang tidak memiliki orang tua yang gemuk. Penelitian ini memiliki tingkat signifikan penelitian yang baik dengan nilai CI 95\% (1.058-2.506) yang memiliki rentang nilai yang erat. 


\section{PEMBAHASAN}

Hasil penelitian yang dianalisis menggunakan uji Chi Square didapatkan bahwa hanya status orang tua yang gemuk yang berhubungan dengan kegemukan pada remaja dan dewasa muda di Kota Samarinda. Tidak dapat dipungkiri bahwa kebiasaan responden terutama dalam kegiatan sehari-hari sangat dipengaruhi oleh keluarga yang merupakan orang terdekat setiap individu (Mayulu, 2013). Kedekatan inilah yang mempengaruhi aktivitas berisiko yang dimiiliki oleh orang tua, misalnya orang tua sering memasak makanan risiko tinggi kegemukan maka makanan inilah yang akan dimakan oleh si anak. Sehingga kegemukan ini lebih disebabkan oleh kebiasaan keluarga itu sendiri (Hendra et al., 2016).

Data Badan Kesehatan Dunia (WHO) menyebutkan jumlah pengidap obesitas di dunia mencapai 650 juta, sementara anak dan remaja berusia 5 - 19 tahun yang mengalami kegemukan sebanyak 340 juta. Data Riset Kesehatan Nasional tahun 2016 juga menunjukkan bahwa sebanyak 20,7 persen penduduk dewasa Indonesia mengalami kegemukan. Angka ini meningkat dibandingkan tahun 2013 yang hanya berjumlah 15,4 persen. Kondisi ini menempatkan Indonesia ke dalam 10 besar negara dengan jumlah pengidap obesitas terbanyak di dunia, seperti yang disebutkan dalam jurnal Lancet tahun 2014.

Sebuah studi menyatakan bahwa jika kedua orang tua memiliki status kegemukan maka sekitar $80 \%$ anaknya akan menderita kegemukan pula, bila salah satu orang tua kegemukan maka peluang anak menjadi kegemukan sebesar $40 \%$, namun jika kedua orang tua tidak kegemukan maka risiko kegemukan pada anak turun menjadi $14 \%$
(Hendra et al., 2016). Melihat beberapa fakta ini maka orang tua harusnya memiliki peranan penting dalam memutus kejadian kegemukan pada anak dengan pintar dalam memilih makanan dengan menghindari makan makana instan, junkfood dan makanan berlemak pada anak. Hal ini akan meningkatkan risiko kegemukan anak (remaja dan dewasa muda) yang nantinya akan berisiko pula pada fase dewasa (Yulnefia, 2015).

$$
\text { Peran orangtua dalam }
$$

memantau penurunan berat badan anak sangat efektif untuk dilakukan. Orangtua menyediakan nutrisi yang seimbang sesuai dengan metode food rules. Seluruh anggota keluarga ikut berpartisipasi dalam program diet, mengubah perilaku makan dan aktivitas yang mendukung keberhasilan anak dalam hal ini yang dimaksud adalah remaja dan dewasa muda, serta menjadi bagian dari keseluruhan program komprehensif tersebut (Nugroho \& Fahrurodzi, 2018). Tetapi sebagian para orang tua mengganggap kegemukan bukan masalah yang serius dan mengganggap bahwa anak nya sehat -sehat saja. Disamping itu, ada beberapa orang tua yang mengatur pola makan anak maupun kegiatan fisik seperti olah raga untuk upaya penurunan berat badan anak yang berlebihan (Dewi, 2015).

Dampak buruk kegemukan terhadap kesehatan, sangat berhubungan erat dengan penyakit serius, seperti tekanan darah tinggi, jantung, diabetes mellitus dan penyakit pernafasan. Dampak lain yang sering diabaikan adalah obesitas dapat mengganggu kejiwaan pada anak, yakni sering merasa kurang percaya diri. Apalagi jika anak sedang dalam masa remaja dan mengalami obesitas, biasanya akan menjadi pasif dan depresi karena sering tidak dilibatkan pada 
kegiatan yang dilakukan oleh teman sebayanya (Praditasari \& Sumarmik, 2018). Beberapa penelitian yang telah dijelaskan terdahulu menunjukkan banyaknya faktor risiko yang menjadi penyebab kejadian overweight pada remaja sehingga menyebabkan tingginya prevalensi overweight pada remaja (Mayulu, 2013). Menurut teori yang telah didapat menunjukkan bahwa overweight akan memberikan dampak negatif terhadap kesehatan fisik dan mental individu untuk masa kehidupan selanjutnya, seperti kolesterol tinggi, hipertensi, diabetes melitus, penyakit jantung, gangguan pernafasan, gangguan sendi dan kanker yang menyebabkan menurunnya angka harapan hidup.

Bertambahnya pengidap obesitas disebabkan oleh banyak faktor. Antara lain kebiasaan konsumsi makanan dan minuman tinggi kalori, rendahnya aktivitas fisik, faktor keturunan, efek samping obat - obatan, kehamilan, kurang tidur, pertambahan usia, dan masalah kesehatan tertentu (seperti sindrom Cushing dan hipertiroidisme). Obesitas berdampak negatif pada kesehatan tubuh secara menyeluruh. Ibu hamil yang mengidap obesitas berisiko mengidap kencing manis, hipertensi, preeklamsia, bayi lahir prematur, bayi berukuran besar, kelainan bawaan pada janin, hingga keguguran. Sedangkan pada anak anak, obesitas meningkatkan risiko penyakit jantung, prediabetes, gangguan tulang, nyeri sendi dan tulang, dan menurunkan rasa percaya diri (Nugroho, Wijayanti, et al., 2020). Orang bertubuh besar sering diperlakukan tidak baik, atau dikenal fenomena fatphobia, sizeism, atau diskriminasi terhadap ukuran. Hal ini tidak boleh dibiarkan karena termasuk body shaming dan berdampak negatif pada kualitas hidup seseorang, termasuk menurunkan rasa percaya diri dan menyebabkan masalah mental (seperti depresi, kecemasan, dan gangguan stres pascatrauma). Pada beberapa kasus, pengidap obesitas rentan mengalami anoreksia dan bulimia, gangguan pola makan yang membuat pengidapnya kehilangan nafsu makan demi bertubuh kurus. Masalah mental yang dialami pengidap obesitas perlu mendapatkan penanganan psikolog atau psikiater (Nugroho, Tianingrum, et al., 2020).

Pada penelitian ini hanya 1 variabel yang berhubungan, hal ini dikarenakan teknik sampling yang digunakan tidak menggunakan random sampling dan pengambilan datanya secara online sehingga pengukuran variabel yang dilakukan berisiko mendapatkan data yang kurang baik karena subjektivitas responden (Teixeira, 2011).

\section{KESIMPULAN}

Orang tua yang memiliki status gemuk akan berpengaruh terhadap kegemukan pada anak. Hal ini dikarenakan perilaku orang tua yang kurang baik dapat ditiru oleh anak dalam penelitian ini adalah remaja dan dewasa muda. Namun variabel lainnya tidak memiliki hubungan dengan kejadian kegemukan pada remaja dan dewasa muda.

\section{SARAN}

Orang tua lebih selektif dalam memasak menu makanan untuk anak dan keluarga, memilih makanan yang rendah lemak seperti makanan yang digoreng dan mengurangi karbohidrat yang terkandung dalam nasi yang menjadi makanan sering dikonsumsi oleh masyarakat Indonesia.

\section{UCAPAN TERIMA KASIH}


Peneliti berterimakasih kepada Kementrian Riset dan Pendidikan Tinggi dan Universitas Muhammadiyah Kalimantan Timur atas dukungan atas penelitian ini sehingga dapat berjalan dengan baik

\section{DAFTAR PUSTAKA}

Caesarianna, D., \& Indriawati, R. (2016). Obesitas Hubungannya dengan Pola Asuh dan Tingkat Penghasilan Orang Tua pada Kelompok Usia 11-13 Tahun. Mutiara Medika: Jurnal Kedokteran Dan Kesehatan, 7(2 (s)), 82-87. http://journal.umy.ac.id/index.p $\mathrm{hp} / \mathrm{mm} /$ article/view/1660/1704

Dewi, M. C. (2015). Faktor-Faktor yang Menyebabkan Obesitas pada Anak. Majority, 4(8), 5356.

Hendra, C., Manampiring, A. E., \& Budiarso, F. (2016). FaktorFaktor Risiko Terhadap Obesitas Pada Remaja Di Kota Bitung. Jurnal E-Biomedik, 4(1), 2-6. https://doi.org/10.35790/ebm.4 .1.2016.11040

Johnson, W. D., Beyl, R. A., Burton, J. H., Johnson, C. M., Romer, J. E., \& Zhang, L. (2015). Use of Pearson's Chi-Square for Testing Equality of Percentile Profiles across Multiple Populations.

Open Journal of Statistics, 05(05), 412-420.

https://doi.org/10.4236/ojs.201 5.55043

Kurdanti, W., Suryani, I., Syamsiatun, N. H., Siwi, L. P., Adityanti, M. M., Mustikaningsih, D., \& Sholihah, K. I. (2015). Faktor-faktor yang mempengaruhi kejadian obesitas pada remaja. Jurnal Gizi Klinik Indonesia, 11(4), 179. https://doi.org/10.22146/ijcn. 22 900

Mahfouz, A., Khan, M., Mostafa, O., Shatoor, A., Daffalla, A., \&
Hassanein, M. (2011). Nutrition, physical activity, and gender risks for adolescent obesity in Southwestern Saudi Arabia.

Saudi Journal of Gastroenterology, 17(5), 318. https://doi.org/10.4103/13193767.84486

Mayulu, N. (2013). Analisa Riwayat

Orang Tua Sebagai Faktor

Resiko. Ejournal Keperawatan, 1(1), 1-7.

Nugroho, P. S., \& Fahrurodzi, D. S. (2018). FAKTOR OBESITAS DAN KOLESTEROL TERHADAP HIPERTENSI DI INDONESIA ( INDONESIAN FAMILY LIFE SURVEY V ) Obesity and Cholesterol Factors on Hypertension In Indonesia ( Data of Indonesian Family Life Survey V ). Ghidza: Jurnal Gizi Dan Kesehatan, 2(2), 44-48. Nugroho, P. S., Tianingrum, N. A., Sunarti, S., Rachman, A., Fahrurodzi, D. S., \& Amiruddin, R. (2020). Predictor risk of diabetes mellitus in Indonesia, based on national health survey. Malaysian Journal of Medicine and Health Sciences, 16(1), 126-130.

Nugroho, P. S., Wijayanti, A. C., \& Sunarti, S. (2020). Obesity and Its Risk Factors Among Adolescent in Indonesia. Malaysian Journal of Medicine and Health Sciences, 16(May), 173-179.

Praditasari, J. A., \& Sumarmik, S. (2018). Asupan Lemak, Aktivitas Fisik Dan Kegemukan Pada Remaja Putri Di Smp Bina Insani Surabaya. Media Gizi Indonesia, 13(2), 117.

https://doi.org/10.20473/mgi.v1 3i2.117-122

Salam, A. (2010). Faktor risiko kejadian obesitas pada remaja. Jurnal MKMI, 6(3), 185-190. Sidiartha, I. G. L., \& Juliantini, N. P. 
L. (2015). Hubungan Riwayat Obesitas Pada Orangtua Dengan

Kejadian Obesitas Pada Anak

Sekolah Dasar. E-Jurnal Medika

Udayana, 3(12), 1-13.

https://ojs.unud.ac.id/index.php

/eum/article/view/11950

Teixeira, E. (2011). The

effectiveness of community-

based programs for obesity

prevention and control. Patient

Intelligence, 63.

https://doi.org/10.2147/pi.s123

14

Yulnefia. (2015). Kejadian

Overweight Pada Remaja Di

Analis Kesehatan Abdurrab

Insidence. Collaborative Medical

Journal, 000, 39-48. 